Vol. 3 No.3 (2020) pp. 104-114

Research Paper

\title{
Evaluation of Operational Loading of the Light-Rail Transit (LRT) in Capital Region, Indonesia
}

\author{
Djoko Wahyu Karmiadji ${ }^{1,2} \square$, Muchamad Gozali², Anwar Anwar ${ }^{2}$, Hedi Purnomo ${ }^{3}$, Muji \\ Setiyo $^{4}$, Ramli Junid ${ }^{5}$ \\ ${ }^{1}$ Department of Mechanical Engineering, Pancasila University, Jakarta 12640, Indonesia \\ 2Technology Center for Strength of Structures, Agency for the Assessment and Application of Technology, \\ Puspiptek, South Tangerang, Indonesia \\ ${ }^{3}$ The Indonesian Railroad Industry (INKA), Madiun 63122, East Jawa, Indonesia \\ ${ }^{4}$ Department of Automotive Engineering, Universitas Muhammadiyah Magelang, Magelang 65172, Indonesia \\ ${ }^{5}$ Structural and Material Degradation Group, College of Engineering, Universiti Malaysia Pahang, Malaysia
}

djokow@univpancasila.ac.id

do) https://doi.org/10.31603/ae.v3i3.3882

Check for updates

Published by Automotive Laboratory of Universitas Muhammadiyah Magelang collaboration with Association of Indonesian Vocational Educators (AIVE)

Article Info

Submitted:

06/08/2020

Revised:

18/09/2020

Accepted:

20/09/2020

Online first:

30/09/2020

\section{Abstract}

In 2015, the Indonesian government issued regulations to accelerate the implementation of integrated Light-Rail Transit (LRT) in the capital region and its surroundings. In order to ensure its operational safety, experimental work is required to test components' strength of the manufactured LRT structures. Following the JIS 7105 standard test method, the strain and deflection of the structures were measured by vertical load, compression, rotation, and threepoint load support test. The critical area estimated in the railroad structure were conducted according to the finite element method, in which strain gauges are installed in areas where the stress concentration exceeds nominal pressure, namely notches, bends, and junction areas. The result shows that the maximum stress on the LRT train structure occurs at the door, where maximum compressive strain value is $-1082 \mu \varepsilon \approx-75.74 \mathrm{MPa}$ on the left and the maximum tensile strain value is $597 \mu \varepsilon \approx 41.79 \mathrm{MPa}$ at the right door. The results of fatigue load analysis represent the average stress $\left(\sigma_{m}\right)$ and voltage amplitude $\left(\sigma_{a}\right)$ at the coordinate system located in the Søderberg triangle. Meanwhile, the camber value with the full vertical load still has a positive value of $3.03 \mathrm{~mm}$, which indicates a safe limit.

Keywords: LRT; Al 6005; JIS 7105; Strain; Stress

\begin{abstract}
Abstrak
Pada 2015, pemerintah Indonesia mengeluarkan regulasi untuk mempercepat implementasi Light-Rail Transit (LRT) terintegrasi di wilayah ibu kota dan sekitarnya. Untuk memastikan keselamatan operasionalnya, pekerjaan eksperimental diperlukan untuk menguji kekuatan komponen struktur LRT yang diproduksi. Mengikuti metode uji standar JIS 7105, regangan dan defleksi struktur diukur dengan uji beban vertikal, kompresi, rotasi, dan beban tiga titik. Perkiraan area kritis pada struktur rel kereta api dilakukan dengan metode elemen hingga, dimana strain gauge dipasang pada area yang konsentrasi tegangannya melebihi tekanan nominal yaitu area takik, tikungan, dan persimpangan. Hasil penelitian menunjukkan bahwa tegangan maksimum pada struktur kereta LRT terjadi di pintu, dimana nilai regangan tekan maksimum adalah $-1082 \mu \varepsilon \approx-75.74 \mathrm{MPa}$ di sebelah pintu kiri dan nilai regangan tarik maksimum $597 \mu \varepsilon \approx 41.79 \mathrm{MPa}$ di pintu kanan. Hasil analisis beban fatik merepresentasikan tegangan rata-rata $\left(\sigma_{m}\right)$ dan amplitudo tegangan $\left(\sigma_{a}\right)$ pada sistem koordinat yang terletak di segitiga Søderberg. Sedangkan nilai camber dengan beban vertikal penuh masih bernilai positif sebesar 3,03 mm yang menunjukkan batas aman.
\end{abstract}

Kata-kata kunci: LRT; Al 6005; JIS 7105; Regangan; Tegangan 


\section{Introduction}

Light-Rail Transit (LRT) supports user mobility rapidly and is regularly compared to other land transportation modes, such as buses and conventional city transportation [1]. In Japan, LRT has replaced the use of private cars and other modes of transportation because it is more convenient and efficient [2]-[4]. The train can run in the existing railway tracks or special types for light trains. The width of its track, which is commonly known as the track gauge, is different in sizes depending on the country, with its standard size being $1435 \mathrm{~mm}$, which is used in America and Europe. Meanwhile in Asia, for example Indonesia, smaller width track of 1067 $\mathrm{mm}$ rail is being used. The LRT can run faster than electric and diesel trains. Higher speed and capacity has made the LRT as an attractive choice for longer routes or regional intercity services [5], [6].

In Indonesia, the technical specifications of a normal speed train has been regulated in the ministry of transportation Regulation Number PM 175 of 2015, in which the type of train is categorized based on its propulsion, namely electric and diesel trains. Furthermore, to accelerate the implementation of light rail in the Capital City and surrounding areas (Figure 1), the Government issued Presidential Regulation number 49 of 2017, which was amended to Regulation Number 98. The construction of the LRT in the capital, is a strategic project to speed up the regional economy and reduce congestion [7]. Infrastructure expansion was entrusted to PT ADI KARYA, a domestic construction company, and the trains as shown in Figure 2 were entrusted to PT. INKA, which is a railway manufacturer.
Learning from several countries, construction of LRT in the capital region of Indonesia not only has a positive impact on the economy, but also on the image and quality of the city [8]-[11].

Taking into account the vitality of the LRT trains, concerning the safety of people and goods, it is necessary for the LRT trains to have sufficient capacity and ability to withstand the load during operation. LRT was designed for a maximum of 258 people, provided that each passenger has 70 $\mathrm{kg}$ in weighs with a maximum capacity of 8 people $/ \mathrm{m}^{2}$ [8], [9]. The load distribution of the train including the equipment is designed for evenly distributed of the weight, and the position of the center of gravity is designed as low as possible to limit the tendency of the train straightening up by maximizing the introduction of adhesives to the rails and minimizing axle loads.

To ensure the strength of the train's components and structures, the manufacturing process is conducted at different stages. Experimental work or testing of components and structures is among one of the stages for optimal design, in which the testing results will beused as a reference load. During testing, load or weight of a train without load/passenger is $34.9-46.5$ tons and denoted as AW0 to represent assigned weight 0 . On the other hand, weight of a train with full load/passengers (258 people) is 52.5 - 66.5 tons and denoted as AW4 to represent assigned weight 4 where both of these weight ranges were taken for LRT with standard rail width (1435 mm) [12], [13]. The trains' construction and components strength must be known to ensure the operational safety status and trains security conditions through design analysis and validation tests.
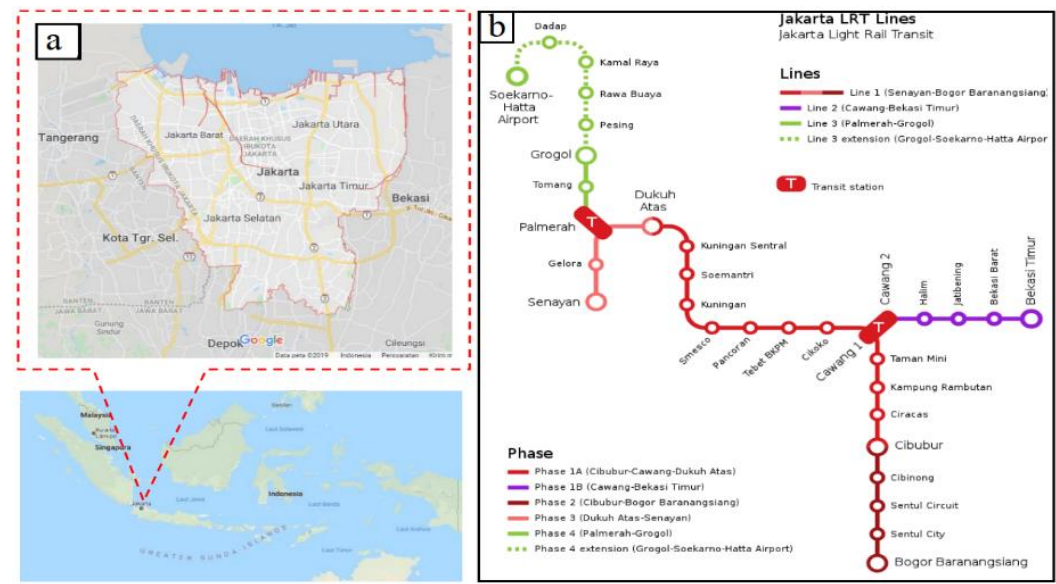

Figure 1. Indonesian Capital City and surrounding areas: (a) Map of Jakarta and (b) Existing LRT lines 


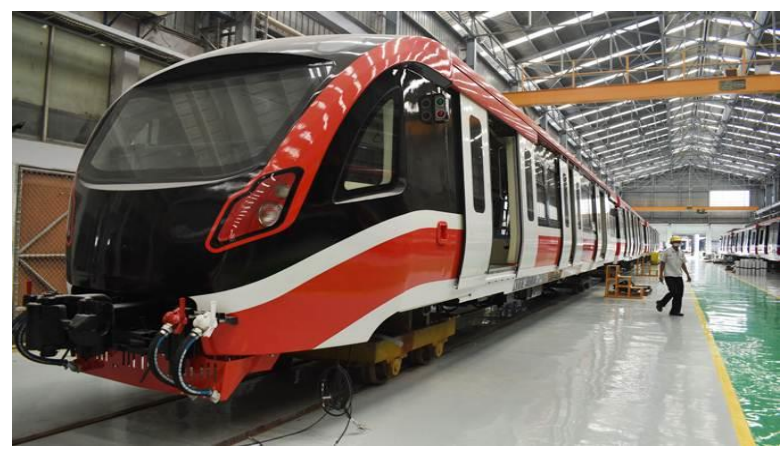

Figure 2. LRT train manufactured by PT. INKA

\section{Method}

The type and direction of the load on the train structure in operation are simulated as vertical, compression, twist, and jacking loads.

\subsection{Test Specimen}

The test specimen is the body structure of the LRT train included with electrical drive equipment at the front and rear of the train set but without the complete set of wheels and bogies, as shown in Figure 3. In addition, the test specimen is also included with lower frame structure, its floor, wall (body) and roof. Test specimens were manufactured by a domestic railway industry.

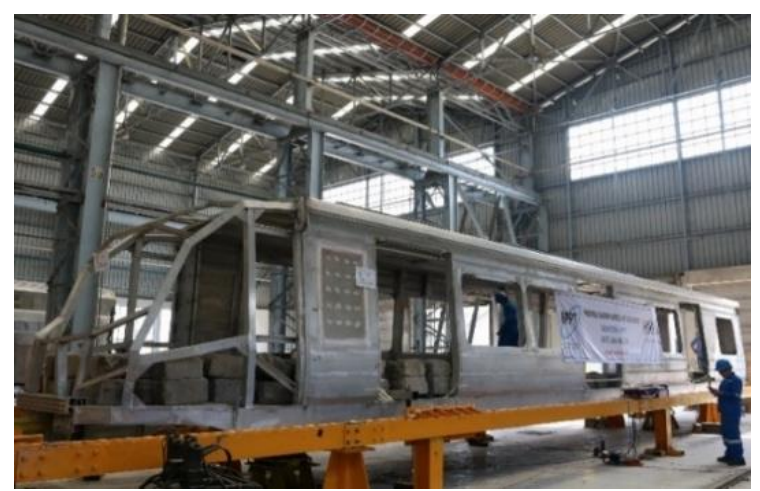

Figure 3. LRT cabin train as a test specimen

The LRT train consists of 3 multiple units, namely 2 motorized cabins (front and rear) and 1 trailer, whereby the passenger capacity of 400 people consists of 80 seats and 320 stands. The passenger capacity of the test body for the motorized cabin (MC) is 132 people, including 26 seated and 106 standing. Based on the manufacturer's data, a standard rail width of 1067 $\mathrm{mm}$ has an MC specifications containing the train weight of 10.359 tons, train length $17,300 \mathrm{~mm}$, the width of the train body is $2,650 \mathrm{~mm}$, height from the roof to rails is $3685 \mathrm{~mm}$; Rail height from the ground of $1000 \mathrm{~mm}$; the interior height of 2,000 $\mathrm{mm}$. The main structure of the MC LRT train (Figure 3) consists of the Middle-End Sill, side sill, Bolster, Floor and Door, which were built by welding systems, made of 6005 aluminum material, with the following specifications: ultimate stress $\left(\sigma_{\text {ult }}\right)=255 \mathrm{MPa}$, yield stress $\left(\sigma_{0.2}\right)=$ $215 \mathrm{MPa}$, modulus of elasticity $(E)=70 \mathrm{GPa}$, Poison Ratio $(v)=0.33$ [14], [15].

\subsection{Test Method of Train Body Structure}

Due to the Regulation No. 175 of the Minister of Transport in 2015, the average speed of LRT trains should not exceed $200 \mathrm{~km} / \mathrm{h}$, and it must be constructed with high strength and a high capability to resist load without experiencing permanent deformation. In this regard, the train should be able to bear a longitudinal compression load of at least $400 \mathrm{kN}$. The test was conducted following the Japanese industry standard JIS E 7105 , for the strength of the trains' body structure against the design load [16]. The strength, rigidity, and other body structures of the electric, locomotive, and passenger trains were determined by method established in the static load test. The load classification in the test standard includes,

- Vertical Load, i.e. train load consisting of components and passengers.

- Compression load, which is the acceleration and deceleration of the trainload and the process of connecting or coupling the train.

- Rotating loads, i.e. loads that occur due to uneven conditions or during an emergency, such as damage to one of the wheel systems.

- Vertical load test at three points, i.e, the process of maintaining and repairing the trains in the field.

Certain criteria which was considered when implementing research methods include: 


\section{Horseblock model}

The train is supported by wheels with several bogies, bolsters, and swing arms. Its structure is connected to the bogie by using bolsters which are set to the horseblock to test the vertical load. The horseblock system between its structure and the bolster is a piece of support equipment that enables longitudinal and rolling directions. Therefore, the support model in the train's vertical load test is determined by the roller model. The support is free from moving and rolling in a longitudinal direction, also eliminating the moment on the horseblock. Based on the longitudinal direction support system, which is due to compression loads, the connection between the trains is found at the knuckle location. One end of the knuckle is connected to a fixed support and the other end is connected to a hydraulic cylinder as a compression load generator.

\section{Vertical load test}

The vertical load test is a simulation of a train structure due to its function as a transportation mode to move goods and people. Large cargo in the form of goods or humans is a vertical load that should be held by the train structure. The railroad structure is designed in 2 loading conditions, namely a tare and a full. The first, which is known as a tare, simulates a condition where the train is empty (no-load). Furthermore, the tare load condition is in the form of components that are above the undercarriage structure.

The results from the calculation is aimed at determining the vertical body load of the carriage given in $\mathrm{Eq}(1)$.

$$
P_{v}=k\left(P_{1}+P_{2}\right)
$$

Where,

$P_{v} \quad=$ vertical load

$k=1.3$ (dynamic coefficient).

$P_{1} \quad=$ Train body weight ready for operation

$P_{2} \quad=$ Total passenger $\times 70 \mathrm{~kg}$

Total passenger $=$ number of chairs + standing passengers (8 passengers $/ \mathrm{m}^{2}$ ).

After applying the above formular, the vertical load of the specimen was calculated to be

- Tare load = 1,3 (10359 kg + 0 kg) = 13466.7 kg $\approx 13.5$ ton

- Full load = 1,3 (10359 kg + $14420 \mathrm{~kg})=32212.7 \mathrm{~kg}$ $\approx 32.2$ ton

The loading method is conducted by burdening the train structure in the form of a bataton load which has been measured by weight. The test load is placed evenly on the surface of the train, according to Figure 4. According to the regulation of the Minister of Transportation No. 175 of 2015, the stress at the critical point of the train body structure, due to maximum load, resulting from tensile and shear stress should not exceed $75 \%$ of the structural material yield.

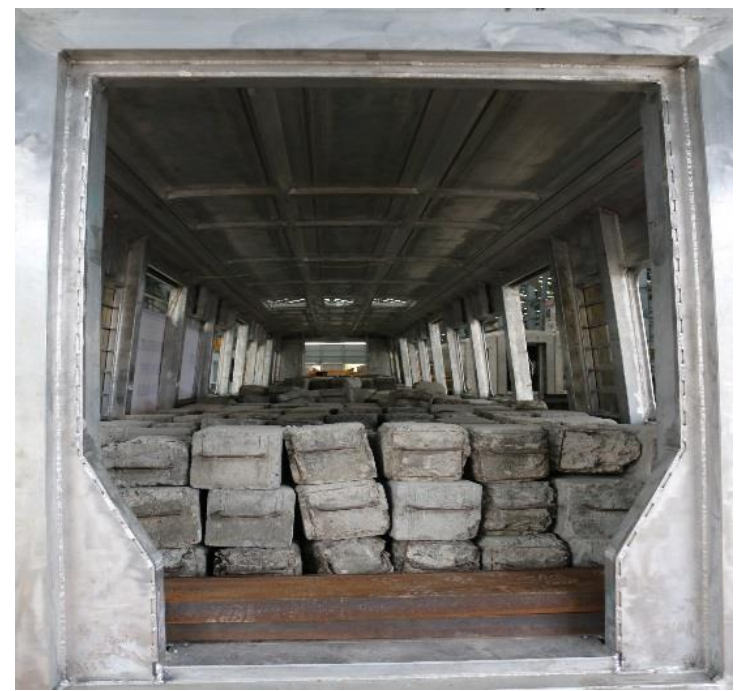

Figure 4. Vertical load test using bataton

\section{Compression load test}

This is a static test that represents the loading of the train structure due to acceleration, deceleration, and the coupling process between trains. Following the regulation transportation minister requirements No. 175 of 2015, which states that the train structure needs to withstand a compression load of 40 tons, with its stress not exceeding $75 \%$ of the yield stress. The structure's compression test load can be divided into two, namely tare load and full load.

Three-point support load test

This test is a simulation of the train structure when supported only at 3 points in its empty state (tare load). To indicate the structure of a raised train, the method of lifting the 3 jacking pad is used.

\section{Twist load test}

This simulates the condition of the train structure when it experiences a twist in the loads as a result of repairs or emergency conditions due to rails damage, bogies, or wheels. The test method is to overload the train structure with a full vertical load (full load), which is performed by jacking one of the pads gradually in a vertical 
direction until it reaches the design load. Its results require a twist or torsional load test, where the stresses that are acting on the construction due to these loads need to be below the fatigue limit of the material.

\subsection{Mechanical Quantity Measurement}

The main purpose of the test activity is to measure the parameters of strain and deflection. These parameters were measured at each stage of the test, namely the vertical load, compression, twist, and three-point support load tests. In calculating the stress as a basis for evaluation, structural strength strain is used. The device used in the measurement of strain is known as a strain gauge. Furthermore, the measurement is conducted on all parts of the train structure to obtain an optimal result, specifically in areas that are estimated to be critical or areas experiencing relatively high stress.

Strain sensors are installed at the point measured, through the process of gluing, to measure the movement that takes place at that location using a strain gauge. The output of the strain sensor in the form of an electrical signal is equivalent to the magnitude of the strain (extension) in the test object. It is connected to the data logger. Factors concerning the configuration of strain gauge installation include calibration factors, temperature, and others which are also known as a correction factor in the programming of the data logger. In addition to the amount of strain, the train structure testing also aims to determine changes in the camber, especially due to vertical loads. The size of the camber is measured using LVDT (linear variable displacement transducer). The output of the LVDT is an electrical signal in which the data can be measured with a data logger.

\subsection{Structure Connection Characteristics}

The process involved in the manufacturing of a train includes the joining of a structural frame made of AL 6005 material through the welding process. The quality of the welded joint used on LRT trains has been verified through standard material static testing to compare critical values in welded joints at risk of fatigue. The aluminum welding test is carried out to validate the welding strength process by the manufacturer following the material and weld joint which is identical to the LRT structural material.

Static testing is conducted by ASTM E8 metal material test methods [17]. Figure 5 represents the test specimens before and after the tensile test, where the average tensile strength value is 278 MPa with an elongation of $16 \%$. Due to the results of the static tensile test on the weld material, the average strength is $176.54 \mathrm{MPa}$.

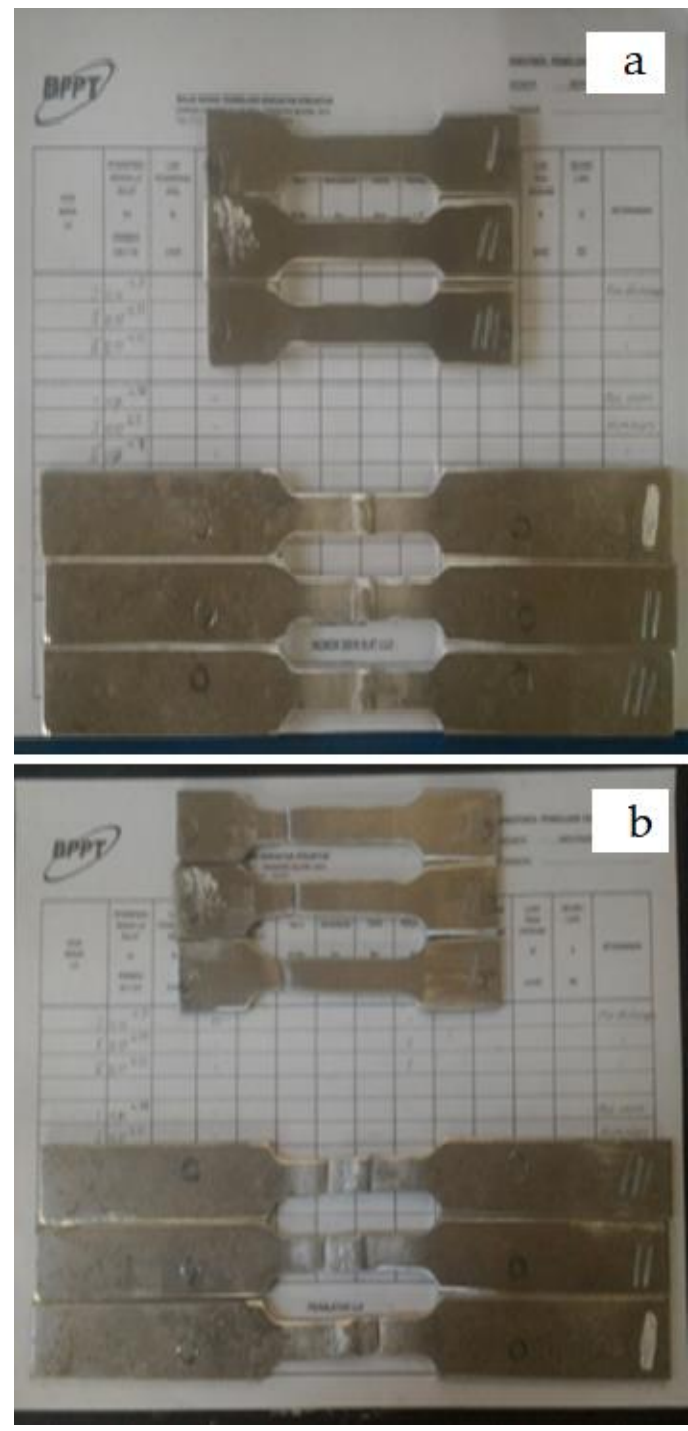

Figure 5. Test specimen of AL6005 before (a) and after (b) tensile test

The weld fracture occurs in the base material in which the maximum strength value has a large difference to the static tensile test of it. Based on the Aluminum-Structural Welding Code from AWS D1.2/D1.2M: 2014 [18], the weld strength maintains its value above the minimum tensile strength of the aluminum weld 6005 (165 MPa). 


\section{Result and Discussion}

\subsection{Design Analysis}

During the test process of the MC LRT train body specimen, it is necessary to estimate the critical area of the train body structure. This estimation was obtained by design analysis using the finite element method as shown in Figure 6, where different colors were used to interpret locations with high-stress values at the point of loading. This is estimated in areas that have
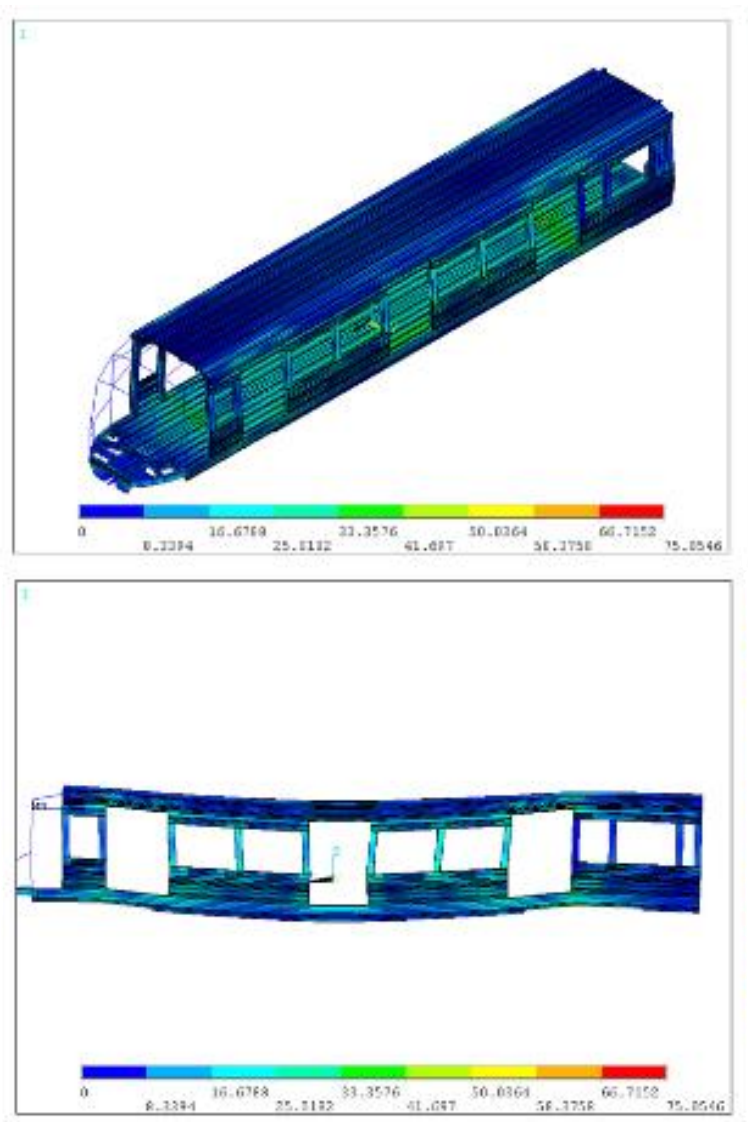

concentrations of stress exceeding nominal stresses, namely notches, bends, junction areas, and others.

Figure 6 shows the results of static test analysis of train body structure similar to Figure 3 whereby the load was adjusted to the test discussed through the finite element method. From the analysis made, the locations of strain gauges installation points are set as shown in the example of strain gauges mounted on Figure 7, this was determined by installing 55 strain gauges.

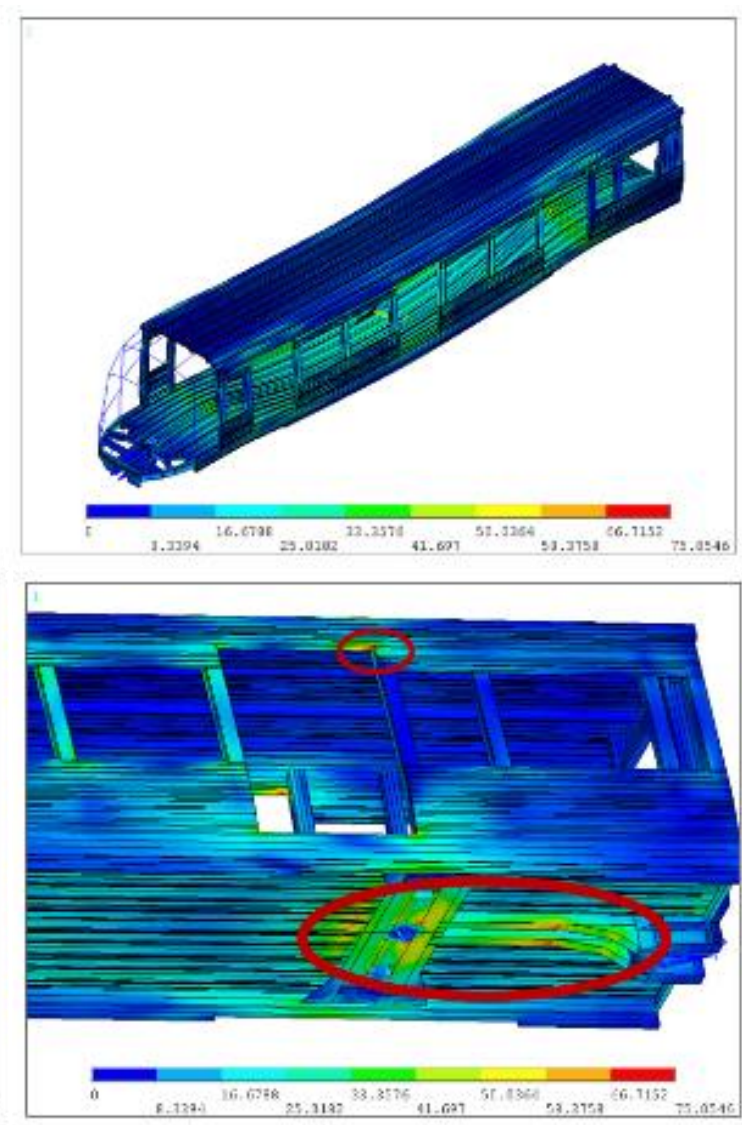

Figure 6. Analysis of critical locations of LRT body structures using FEM
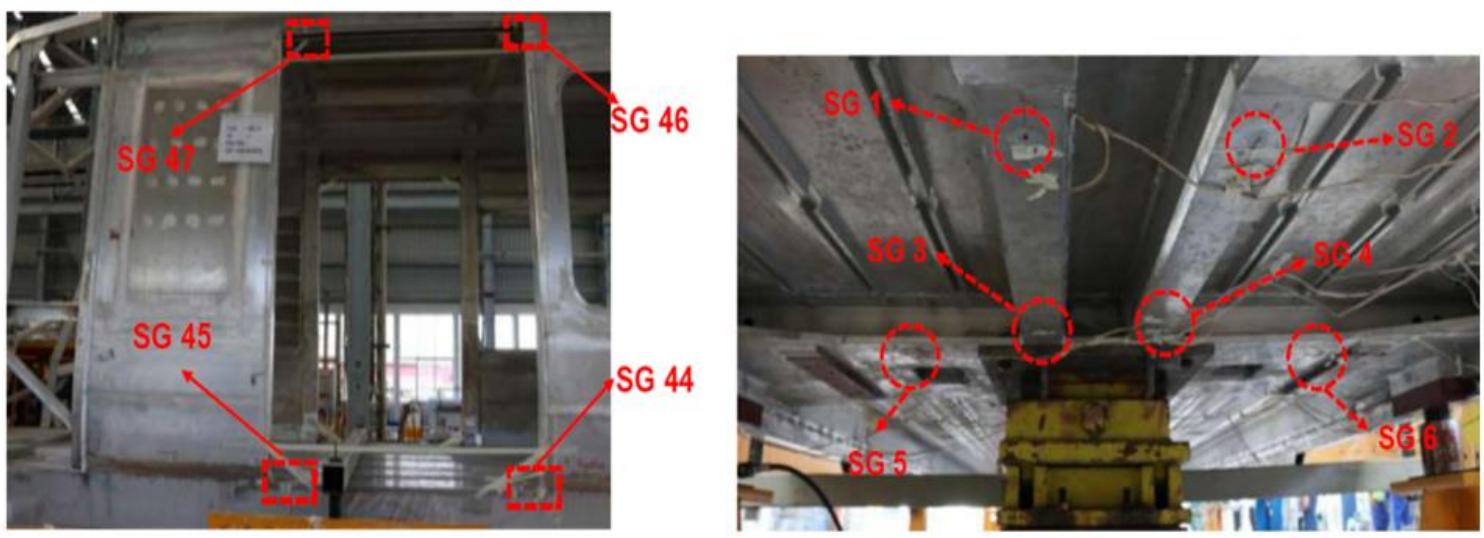

Figure 7. Example of a strain gauges installation location 


\subsection{Static Strength Verification}

One of the parameters used in assessing the characteristics of a train's structure is to understand the stress that occurs at some predicted or critical point. The value of stress was obtained based on the measurement data in the form of strain. There are two types of strain sensors used for measurement, namely the single and the rosette type with an angle of $45^{\circ} / 90^{\circ}$ (see Figure 8) [19].

The relationship between strain and stress for a single strain gauge type can be represented by Hooke's law as presented in Eq. (2) as follows.

$$
\sigma=\varepsilon E
$$

where, $\sigma=$ stress $(\mathrm{MPa}), \varepsilon=$ strain $(\mu \varepsilon)$, and $E=$ modulus of elasticity (MPa).

For the type of rosette strain gauge with a $45^{\circ} / 90^{\circ}$ angle, the Eq. (3) is used [19]:

$$
\sigma_{1,2}=\frac{E}{2}\left[\left(\frac{\varepsilon_{a}+\varepsilon_{c}}{1-v}\right) \pm \frac{\sqrt{2}}{1+v} \sqrt{\left(\varepsilon_{a}-\varepsilon_{b}\right)^{2}+\left(\varepsilon_{b}-\varepsilon_{c}\right)^{2}}\right]
$$

where:

$$
\begin{aligned}
\sigma_{1,2} & =\text { principle stresses of } \sigma_{1} \text { and } \sigma_{2}(\mathrm{MPa}) . \\
E & =\text { modulus of elasticity }(\mathrm{MPa}) . \\
v & =\text { Poison's ratio } \\
\varepsilon_{a} & =\text { strain of } 0^{\circ} \\
\varepsilon_{b} & =\text { strain of } 45^{\circ} \\
\varepsilon_{c} & =\text { strain of } 90^{\circ}
\end{aligned}
$$

Meanwhile, the equivalent stress can be calculated by using Von Mises criteria according to Eq. (4) [19]:

$$
\sigma_{\mathrm{eq}}=\sqrt{\left(\sigma_{1}^{2}+\sigma_{2}^{2}-\sigma_{1} \sigma_{2}\right)}
$$

The application of Eq. (2), (3) and (4) is exemplified from the results of the three-point support load test, where the measurement results for the single strain gauge type have a maximum negative strain value of $-1082 \mu \varepsilon$ and a maximum positive value of $597 \mu \varepsilon$, and also the largest value for the type of strain gauge rosette is $\varepsilon_{\mathrm{a}}=82 \mu \varepsilon, \varepsilon \mathrm{b}$ $=-36 \mu \varepsilon, \varepsilon_{\mathrm{c}}=182 \mu \varepsilon$.

Equation (2) is used to calculate the amount of stress at the point of a single strain gauge. The deformation with the largest negative strain value of the application is as follows:

$$
\begin{aligned}
\sigma & =\varepsilon E \\
& =-1082(\mu \varepsilon) \times 70000(\mathrm{MPa}) \\
& =-1082 \times 10^{-6} \times 70000(\mathrm{MPa}) \\
& =-75,74 \mathrm{MPa} .
\end{aligned}
$$

Therefore, the maximum negative voltage value that occurs is $-75.74 \mathrm{MPa}$ and the maximum positive value is $41.79 \mathrm{MPa}$. Meanwhile, based on the application of Eq. (3) and (4) by entering the measurement value of the rosette strain gauge, an equivalent stress value of $21.11 \mathrm{MPa}$ is obtained as presented in Table 1.

The results of deformation measurements through a single strain gauge sensor are shown in Table 1, where the figures presented are only the largest numbers in each type of strain gauge and its location. For the measurement results of the strain gauge type, rosette is shown in Table 2, where it is only installed on the floor.

For each test method with a given load according to the requirements, the largest deformation is indicated by the magnitude of the strain measurement values listed in Table 1 and Table 2. The largest deformation location in this table is following the estimation in the simulation of the finite element method in Figure 6, namely, in the door area. The greatest strain value occurs at the door (left) location under the three-point support load test conditions for strain and negative stress $(-1082 \mu \varepsilon$ and $-75.74 \mathrm{MPa})$. While the strain value and positive stress values are (597 $\mu \varepsilon$ and $41.79 \mathrm{MPa}$ ) at the door (right) location in
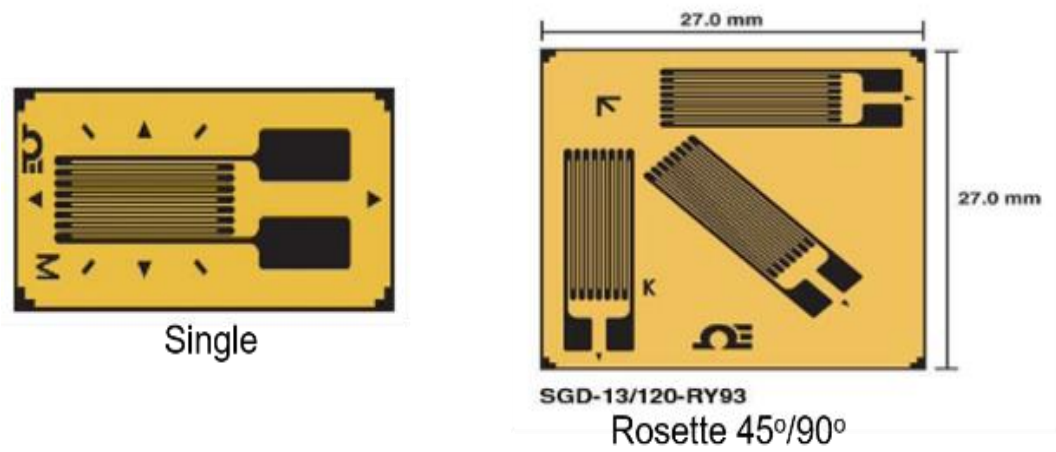

Figure 8. Shows a strain gauge configuration for single and rosette type $45^{\circ} / 90^{\circ}$ 
Table 1. Single strain gauge deformation values

\begin{tabular}{|c|c|c|c|c|}
\hline \multirow{2}{*}{ No } & \multirow{2}{*}{ Load Type } & $\mathrm{e}_{\mathrm{a}}, \mathrm{eb}_{\mathrm{b}} \mathrm{e}_{\mathrm{c}}$ & $\mathrm{s}$ & \multirow{2}{*}{ Location } \\
\hline & & $(\mu \mathrm{e})$ & $(\mathrm{MPa})$ & \\
\hline \multirow[t]{2}{*}{1} & Vertical tare & -308 & -21.56 & Door (left) \\
\hline & & 238 & 16.66 & Door (right) \\
\hline \multirow[t]{2}{*}{2} & Vertical tare + compr $40 \mathrm{t}$ & -537 & -37.59 & End center sill \\
\hline & & 259 & 18.13 & Door (right) \\
\hline \multirow[t]{2}{*}{3} & Vertical Full & -930 & -65.10 & Door (left) \\
\hline & & 577 & 40.39 & Door (right) \\
\hline \multirow[t]{2}{*}{4} & Vertical Full + compr $40 t$ & -1031 & -72.17 & Door (right) \\
\hline & & 597 & 41.79 & Door (right) \\
\hline \multirow[t]{2}{*}{5} & Full load + Twist (Torque) & -913 & -63.91 & Door (right) \\
\hline & & 536 & 37.52 & Door (right) \\
\hline \multirow[t]{2}{*}{6} & Tare Load +3 Points & -1082 & -75.74 & Door (left) \\
\hline & & 578 & 40.46 & Door (left) \\
\hline
\end{tabular}

Table 2. Rosette strain gauge deformation values

\begin{tabular}{llrc}
\hline \multirow{2}{*}{ No } & \multirow{2}{*}{ Load Type } & $\mathrm{e}_{\mathrm{a}, \mathrm{e}, \mathrm{e}} \mathrm{c}$ & $\mathrm{s}$ \\
\cline { 3 - 4 } & & $(\mu \mathrm{e})$ & $(\mathrm{MPa})$ \\
\hline 1 & Vertical tare & 51 & 6.33 \\
& & 61 & 5.58 \\
& & 63 & 5.99 \\
\hline 2 & Vertical tare + compr 40 t & -80 & 4.62 \\
& & 10 & -4.10 \\
& & 85 & 7.56 \\
\hline 3 & Vertical Full & 137 & 26.69 \\
& & 160 & 17.30 \\
& & 284 & 23.45 \\
\hline 4 & Vertical Full + compr 40 t & 3 & 24.78 \\
& & 111 & 7.92 \\
& & 310 & 21.92 \\
\hline 5 & Full load + Twist (Torque) & 153 & 27.27 \\
& & 180 & 18.91 \\
& & 289 & 24.20 \\
\hline 6 & Tare Load + 3 Points & 82 & 23.02 \\
& & -36 & 4.57 \\
& & 182 & 21.11 \\
\hline
\end{tabular}

the vertical load test conditions of 40 tons. From the measurement results of the rosette strain, the largest value of $\sigma \varepsilon$ is $24.20 \mathrm{MPa}$. The main structure of the MC LRT train is made of aluminum 6005 with the ultimate stress specification $\mathrm{Su}=255 \mathrm{MPa}$, the yield stress $S y=$ $215 \mathrm{MPa}$ [14], [15], while the minimum tensile strength of aluminum-weld specimen $6005=165$ MPa [18]. The LRT can withstand a compression load of 40 tons, with the stress not to exceed $75 \%$ of its yield. The stress values in Table 1 and Table 2 are still far below the required standard stress values of $75 \%$ of its yield in the basic material or the tensile strength of the welded joint. The LRT, which was designed with AL 6005 material against the loading that has been determined by government regulations as well as the requirements for welding connections, has been fulfilled.

\subsection{Fatigue Strength Verification}

In operational conditions, the LRT structure must be able to withstand static and dynamic loads. The stress value from the analysis of the static mechanical characteristics of AL 6005 material as described above due to the operational test load obtained, is proven to be far below the material strength value of both the base material 
and welds which has been multiplied by a factor of $(75 \%)$. The analysis of mechanical characteristics due to dynamic loads is carried out by referring to the load values set by Ministerial Regulation, where the LRT can accept loads up to 40 tons which are used as dynamic loads. Specific loading standards for determining the characteristics do not exist, only the distortion load of the JIS E 7106 with a load of $40 \mathrm{kN} . \mathrm{m}$, is a reference to train fatigue load standard [20], [21].

The dynamic strength of the LRT structure is identified by the fatigue life of the material used. To avoid its failure, the stress due to the trainload cannot exceed the material fatigue stress (AL 6005), which is $S_{e}=88 \mathrm{MPa}$ [22]. The LRT train structure experiences various dynamic loads during operation. When the maximum static test is adopted as the loading condition of the train body structure and the fatigue strength needed is considered safe if the maximum stress that occurs due to the maximum load on the static test is still below the fatigue limit/endurance stress of material [20].

Several methods use various curves that connect the limit of fatigue strength $\left(S_{e}\right)$ on the ordinate axis of the alternating stress amplitude $\left(\sigma_{a}\right)$ to yield strength $\left(S_{y}\right)$, ultimate strength $\left(S_{u}\right)$, a fracture or fatigue strength ( $\sigma \mathrm{f})$, on the abscissa axis of average stress $\left(\sigma_{m}\right)$. Analysis with this method is generally carried out in cases made by Soderberg (Eq. 5), Goodman (Eq. 6), Gerber (Eq. 7), and Morrow (Eq. 8) which are explored in the curve in Figure 9 [23].

$$
\begin{aligned}
& \text { Soderberg } \rightarrow \frac{\sigma_{\mathrm{a}}}{\mathrm{S}_{\mathrm{e}}}+\frac{\sigma_{\mathrm{m}}}{\mathrm{S}_{\mathrm{y}}}=1 \\
& \text { Goodman } \rightarrow \frac{\sigma_{\mathrm{a}}}{\mathrm{S}_{\mathrm{e}}}+\frac{\sigma_{\mathrm{m}}}{\mathrm{S}_{\mathrm{u}}}=1 \\
& \text { Gerber } \rightarrow \frac{\sigma_{\mathrm{a}}}{\mathrm{S}_{\mathrm{e}}}+\left(\frac{\sigma_{\mathrm{m}}}{\mathrm{S}_{\mathrm{u}}}\right)^{2}=1 \\
& \text { Morrow } \rightarrow \frac{\sigma_{\mathrm{a}}}{\mathrm{S}_{\mathrm{e}}}+\frac{\sigma_{\mathrm{m}}}{\mathrm{S}_{\mathrm{f}}}=1
\end{aligned}
$$

The Søderberg method analysis is a minimum requirement to get the fatigue safety value according to the stress function curve in Figure $\mathbf{1 0 .}$ This consideration is based on the train structural material, namely aluminum alloy $\mathrm{Al} 6005$, where the reference for the analysis of design stress to static strength is yield stress $\left(S_{y}=215 \mathrm{MPa}\right)$ and fatigue stress limits $\left(S_{e}=88 \mathrm{MPa}\right)$ for dynamic forces.

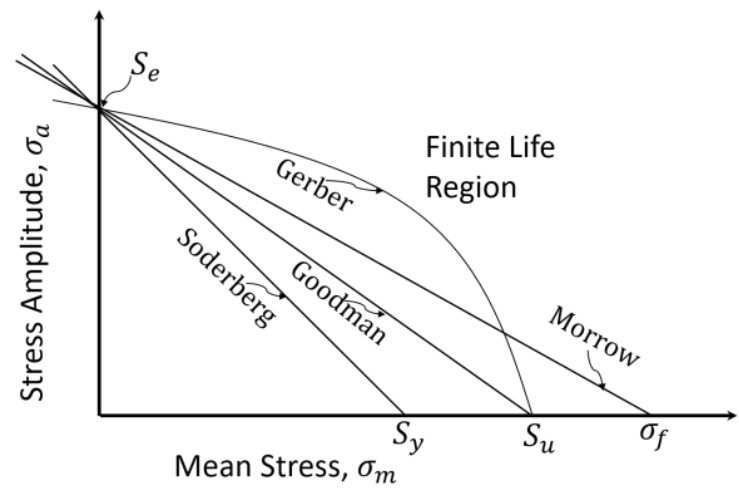

Figure 9. Curves of fatigue stress equations

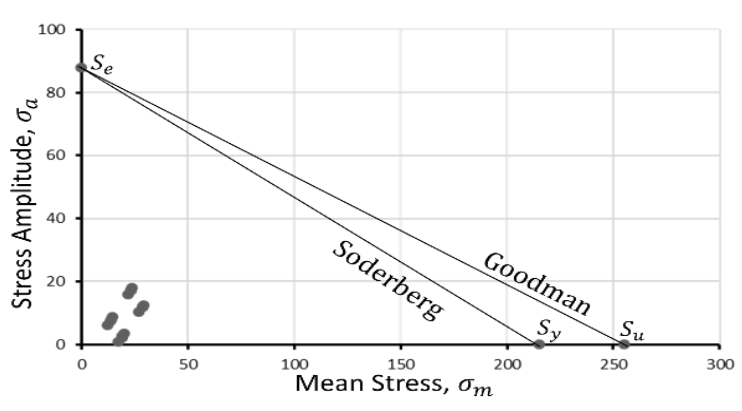

Figure 10. Fatigue stress analysis of operational loads

By assuming the random dynamics loads having various average and amplitude stress values alongside those in Table 1and Table 2, the vertical load tare is chosen and the minimum stresses are $\sigma=16.66 \mathrm{MPa}$ and $\sigma \mathrm{e}=5.99 \mathrm{MPa}$, respectively. The maximum stresses are determined from the stress values greater than the minimum values chosen in Table 1 and Table 2. Therefore, the average stress $\left(\sigma_{m}\right)$ and amplitude stress $\left(\sigma_{a}\right)$ can be calculated from the minimum and the maximum stresses and are presented in Figure 10. In the coordinate system of the stress axes, the values of the maximum tensile stresses in the test are still below the material fatigue strength $\left(S_{e}\right)$. As a result, the fatigue strength properties in the aluminum alloy structure material are still far above the operational load.

\subsection{Camber}

Each structure that experiences bending loads, are always designed with a certain camber magnitude, as well as a train body structure. Camber is defined as the lowest distance between the midpoints of the trains' stretch structure to the fulcrum, see Figure 11a. The design of the railway structure requires that the camber is always positive even if it is loaded with maximum load. 
Positive camber means that the camber value must be above the straight line between the pedestals.

To measure the camber, a linear displacement transducer (LVDT) is installed in several places, namely the middle of the stretch, the pedestal, and the end of the train. Figure $\mathbf{1 1}$ b shows an example of an LVDT installation on a specimen. The LVDT measurement results for deflection in the middle position of the stretch or camber changes when the maximum vertical load conditions (full load) is $8.47 \mathrm{~mm}$. While the structure of the MC type LRT train is designed with camber $\mathrm{c}=11.5 \mathrm{~mm}$, the size of the camber at full load is $3.03 \mathrm{~mm}$ above the horizontal plane. This condition is following the MC type LRT train structure design requirements.

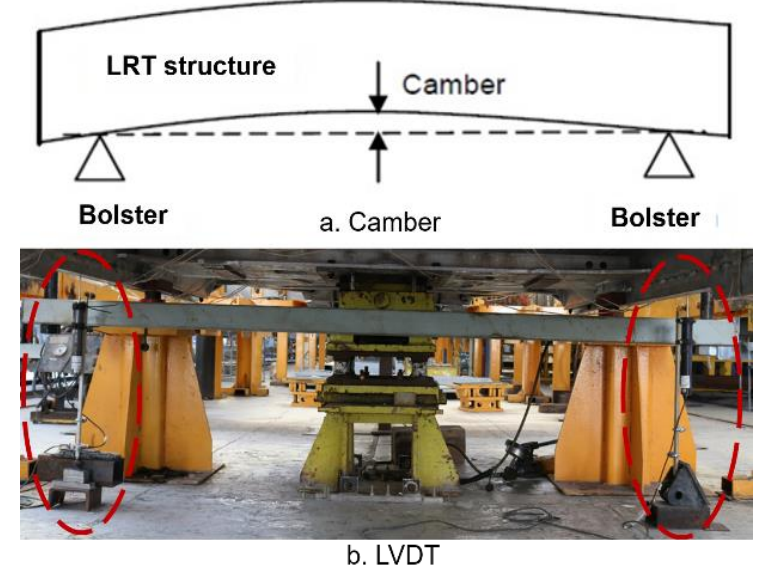

Figure 11. Camber and LVDT set up

\section{Conclussion}

The results of manufacturing verification through structural strength to the maximum operating load indicate that the mechanical characteristics or strength values of the basic material and the weld joints are still far above the stress value. Furthermore, due to the maximum loading given following the regulations or test method standards, the maximum stress values on the LRT train structure occur at the doors where the maximum compressive strain value is $-1082 \mu \varepsilon$ $\approx-75.74 \mathrm{MPa}$ on the left door and the maximum tensile strain value is $597 \mu \varepsilon \approx 41.79 \mathrm{MPa}$ at the right door. Meanwhile, the maximum strain values of the SG rosette type on the floor of the train are $\varepsilon a=82 \mu \varepsilon, \varepsilon b=-36 \mu \varepsilon, \varepsilon c=182 \mu \varepsilon$ or equivalent stress $\left(\sigma_{\varepsilon}\right)=24.20 \mathrm{MPa}$. The results of fatigue load analysis based on the maximum stress values when the loads are empty shows that the average stress values $\left(\sigma_{m}\right)$ and the alternating stress amplitudes $\left(\sigma_{a}\right)$ in the coordinate system are still located in the Soderberg triangle. Therefore, the stress values due to dynamic operating loads are still below the material fatigue stress limit $\left(S_{e}\right)$. Likewise, the camber value with the full vertical load still has a positive value of $3.03 \mathrm{~mm}$, still within safe limits. Finally, the results of the analysis and evaluation of the LRT structure design with aluminum alloy AL6005 show that the mechanical characteristics of the train structure material still have values above the stresses and deformations due to the maximum loading required.

\section{Acknowledgment}

The author would like to thank all those who have helped this research, especially the mechanical testing Laboratory of the Center for Structural Strength Technology (B2TKS), the Agency for the Assessment and Application of Technology (BPPT) and the Indonesian Railroad Industry (INKA).

\section{Author's Declaration}

\section{Authors' contributions and responsibilities}

The authors made substantial contributions to the conception and design of the study. The authors took responsibility for data analysis, interpretation and discussion of results. The authors read and approved the final manuscript.

\section{Funding}

No funding information available from the authors.

\section{Availability of data and materials}

All data are available from the authors.

\section{Competing interests}

The authors declare no competing interest.

\section{Additional information}

No additional information from the authors.

\section{References}

[1] H. M. Taki, M. M. H. Maatouk, E. M. Qurnfulah, and M. O. Aljoufie, "Planning TOD with land use and transport integration: a review," Journal of Geoscience, Engineering, Environment, and Technology, vol. 2, no. 1, p. 84, 2017.

[2] P. Chorus and L. Bertolini, "Developing transit-oriented corridors: Insights from 
Tokyo," International Journal of Sustainable Transportation, vol. 10, no. 2, pp. 86-95, 2016.

[3] J. Calimente, "Rail integrated communities in Tokyo," Journal of Transport and Land Use, vol. 5, no. 1, pp. 19-32, 2012.

[4] JTPA, “Japan's Light-Rail Transit," 2012. [Online].

Available: http://www.jtpa.or.jp/eng/contents/pdf/3_L RT2.pdf.

[5] T. Weng, "Analyzing Benefits of Urban Development and City Tourism with Light Rail Transit in Kaohsiung," IOSR Journal of Business and Management (IOSR-JBM), vol. 18, no. 11, pp. 64-71, 2016.

[6] C. D. Higgins, M. R. Ferguson, and P. S. Kanaroglou, "Light rail and land use change: Rail transit's role in reshaping and revitalizing cities," Journal of Public Transportation, vol. 17, no. 2, pp. 93-112, 2014.

[7] H. Z. Rahman, P. Miraj, and A. Andreas, “Exploring public-private partnership scheme in operation and maintenance stage of Railway Project," Sustainability (Switzerland), vol. 11, no. 22, 2019.

[8] F. Ferbrache and R. D. Knowles, "City boosterism and place-making with light rail transit: A critical review of light rail impacts on city image and quality," Geoforum, vol. 80, pp. 103-113, 2017.

[9] M. F. Dziauddin, "Estimating land value uplift around light rail transit stations in Greater Kuala Lumpur: An empirical study based on geographically weighted regression (GWR)," Research in Transportation Economics, vol. 74, no. October 2018, pp. 10-20, 2019.

[10] A. C. Nelson, P. Stoker, and R. Hibberd, "Light rail transit and economic recovery: A case of resilience or transformation?," Research in Transportation Economics, vol. 74, no. February 2018, pp. 2-9, 2019.

[11] E. S. Park and I. N. Sener, "Traffic-related air emissions in Houston: Effects of light-rail transit," Science of the Total Environment, vol. 651, pp. 154-161, 2019.

[12] Valley Metro, "Design Criteria Manual,"
Phoenix metropolitan area, 2018.

[13] ETS, "City of Edmonton - LRT Design Guidelines," Edmonton, 2017.

[14] Nedal, "ALLOY DATA SHEET EN-AW 6005A [AlSiMg(A)] (Type:Medium strength extrusion alloy)," Nedal Aluminium, 2018. [Online]. Available: https://www.nedal.com/wpcontent/uploads/2019/07/NEDAL_Datasheet -6005A.pdf. [Accessed: 12-Jan-2020].

[15] Aalco Metals Limited, "Aluminium Alloy Commercial Alloy - 6005A - T6 Extrusion," 2018. [Online]. Available: http://www.aalco.co.uk/datasheets/Alumini um-Alloy-6005A-T6-Extrusion_157.ashx.

[Accessed: 12-Jan-2020].

[16] JIS, “JIS E 7105:2006 Rolling stock-Test methods of static load for body structures." Japanese Standards Association, Tokyo, 2006.

[17] ASTM, “ASTM E8 Standard Test Methods for Tension Testing of Metallic Materials." ASTM International, Conshohocken, 2013.

[18] American Welding Society, Structural Welding Code-Aluminium. New York: American National Standard Institute, 2014.

[19] J. W. Dally and W. F. Riley, Experimental Stress Analysis. New York: Mcgraw-Hill College, 1991.

[20] C. Wang, C. Wang, C. Liu, and Y. Jiang, "Research on Fatigue Test Method of Car Body for High-speed trains," IOP Conference Series: Earth and Environmental Science, vol. 189, no. 6, 2018.

[21] JIS, “JIS E 7106:2006 Rolling stock-General requirements of carbody structures for passenger car." Japanese Standards Association, Tokyo, 2006.

[22] MakeItFrom.com, "6005A-T6 Aluminum," 2019. [Online]. Available: https://www.makeitfrom.com/materialproperties/6005A-T6-Aluminum. [Accessed: 12-Jan-2020].

[23] J. Bannantine, Fundamentals of Metal Fatigue Analysis. New Jersey: Prentice Hall, 1990. 